\title{
Armenia and Europe: Foreign Aid and Environmental Politics in the Post-Soviet Caucasus
}

\author{
Pål Wilter Skedsmo \\ London: I.B.Tauris 2019 \\ 266 sider. ISBN 9781788311748
}

Anmeldt av Lene Wetteland [leiar av Russlandsavdelinga, Den norske Helsingforskomité, lw@nhc.no]

Etter årevis med stagnasjon og fattigdom har det brått skjedd mykje i Armenia, særleg dei siste to til tre åra. Ein sensasjonell folkeleg revolusjon fann stad i april 2018, og etter frie val kom revolusjonsleiarane til makta i desember same året. Sidan har særleg miljødebatt rundt mogleg utvinning av gull i fjellet Amulsar nær spa-byen Jermuk ført til mykje protest frå folket, og dårlege bortforklaringar frå det nye regimet som ikkje heilt veit korleis dei skal løyse situasjonen - skvist mellom ønska frå folket som fekk dei til makta, krava frå internasjonale aktørar, og sabotasje frå russisk-støtta krefter. Ei bok som går i djupna på nettopp sivilsamfunnet, miljøvern, internasjonal bistand og Armenia og Europa er derfor kjærkommen, og Armenia and Europe: Foreign Aid and Environmental Politics in the Post-Soviet Caucasus lovar å gjere nettopp det.

Pål Wilter Skedsmo var ansvarleg for implementering av eit prosjekt i Armenia i Fridtjof Nansen Institutts regi i perioden 2005-2010, og følgde Armenia og prosessen med den sokalla Aarhus-konvensjonen også etterpå. Prosjektet var støtta av det norske utanriksdepartementet, og skulle i samarbeid med relevante armenske departement betre kunnskap og gjennomføring av berekraftig utvikling i Armenia, herunder den sentrale Konvensjonen om tilgang til miljøinformasjon, allmenn deltaking $i$ avgjerdsprosessar og tilgang til rettsmidlar $i$ saker om miljø, Aarhus-konvensjonen. I 2017 forsvarte Skedsmo doktorgraden i sosialantropologi sin på dette tema, og ei omarbeiding av doktoravhandlinga blei så gitt ut som den omtalte boka i 2019 .

Første kapittel av boka set både tema og Armenia litt i kontekst, før to empiriske kapittel og eit konklusjonskapittel. Det er her interessant at Skedsmo mellom anna tek Armenia ut frå den tradisjonelle post-sovjetiske og post-sosialistiske sfæren, og legg til eit post-kolonialistisk perspektiv. Empirien går først inn på Aarhus-konvensjonen som del av ei europeifisering av Armenia, og korleis norske aktørar, internasjonale 
organisasjonar og det armenske sivilsamfunnet nytta seg av konvensjonen på ulike måtar for å oppnå ulike mål i den perioden Skedsmo følgde.

Andre del er ei særs ærleg skildring av korleis det konkrete prosjektet Skedsmo styrte utvikla seg frå pilot via noko krunglete implementering til å bli lagt ned. Her er det fleire underhaldande episodar frå eit post-sovjetisk Armenia, og vurdering av nokre av dei kamelane ein må svelge både ovanfor den norske donoren når det gjeld det prosjektadministrative, særleg innføringa av spesifikke prosjektverktøy som «LOG frame», og ovanfor sosiale armenske samarbeidspartnarar i felt. Og sist, men ikkje minst, korleis dei to versjonane av prosjektet etter kvart beveger seg lenger og lenger frå kvarandre.

Dessverre er boka, særleg dei første kapitla, veldig tunglesen, og kunne med fordel ha blitt omarbeida enno meir frå doktoravhandlinga for å nå ut betre til oss som ikkje er sosialantropologar, men som også er interesserte i regionen eller tema. Dette ville også hjelpt lesaren å betre følgje forfattarens resonnement om korleis hans observasjonar seier noko om "Armenia and Europe", som tittelen og undertittelen lovar. Til dømes er det element ved den administrative prosjektgjennomføringa andre kunne tenkast å ville ha løyst annleis, og påstandar om sivilsamfunnets rolle som overraskar, slik at slutningane ikkje nødvendigvis er heilt klare for lesaren.

Det er også overraskande at den sensasjonelle revolusjonen, der både sivilsamfunn, miljøvern, europeifisering og post-sovjetisk styresett spelte ei sentral rolle, ikkje er nemnd. Det ligg i fagets og doktorgradens natur at sjølve forskinga ligg nokre år tilbake i tid, men den avgjerande omveltinga skjedde nesten to år før boka kom ut. Ei setning burde ha blitt prioritert, om ikkje anna i forordet. Utelatinga gjev inntrykk av at boka er noko utdatert sjølv om ho, satt i riktig kontekst, absolutt viser eit godt bilete av korleis Armenia var under det førre styret med meir post-sovjetisk arv, og korleis dette er nyttig bakgrunn for utfordringane landet møter i dag. Med dagens protestbilete i landet ville det vera ein enno viktigare kontekst å ha med seg for å nytta informasjonen og analysen vidare, og ikkje minst aktualisere forskinga. 